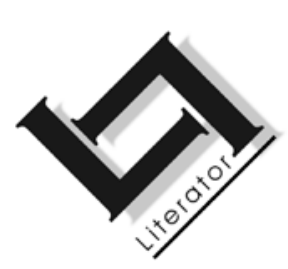

\title{
S.M. Guma and the Sesotho historical novel: an Afrocentric perspective
}

\author{
T.J. Selepe \\ School of Languages \\ Vaal Triangle Campus \\ North-West University \\ VANDERBIJLPARK \\ E-mail: Thapelo.Selepe@nwu.ac.za
}

\begin{abstract}
S.M. Guma and the Sesotho historical novel: an Afrocentric perspective

Afrocentricity seems to be emerging as one of the potent critical tools that could be used to re-establish and qualify African cultural identity through literary study among others. The primary objective of this movement is to reinterpret world history from an African perspective. This article will therefore examine some historical features of S.M. Guma's novels from the 1960s to the 1990s from an African perspective. By applying the Afrocentric paradigm this will attempt to demonstrate how material conditions of the period have provided useful raw materials for the Sesotho historical novel, which tends to illuminate a better understanding of the Basotho culture, history, identity and nationhood.
\end{abstract}

\section{Opsomming}

\section{S.M. Guma en die historiese roman in Sesotho: 'n Afrosentriese perspektief}

Afrosentrisiteit is skynbaar besig om na vore te kom as een van die kragtige kritiese werktuie wat gebruik sou kon word om Afrika-kulturele identiteit deur literatuurstudie te herbevestig en te kwalifiseer. Die primêre doel van hierdie beweging is om wêreldgeskiedenis vanuit 'n Afrika-perspektief te herinterpreteer. Hierdie artikel sal daarom ondersoek instel na sekere historiese kenmerke van S.M. Guma se romans van die sestiger tot die negentigerjare uit 'n Afrika-perspektief. Deur die Afrosentriese paradigma toe te pas, sal hierdie artikel poog om aan te toon hoe materiële toestande van die periode nuttige onbewerkte 
materiaal vir die Sotho historiese roman verskaf het, lig kan werp op 'n beter begrip van die Basotho-kultuur, -geskiedenis, - identiteit en -nasieskap.

\section{Introduction}

Oyebade (1990:233) argues that "The subject matter of the Afrocentric paradigm is its displacement of Africa at the centre of any analysis of African history and culture." On the same note, Keto (quoted by Oyebade, 1990:233) suggests that this approach is valid because "The Afro-centred perspective of history rests on the premise that it is valid to posit Africa as a geographical and cultural starting base in the study of peoples [of Africa and] of African descent."

Furthermore, considering that the consciousness of cultural and national identities has become critical in the era of globalisation, Afrocentricity is also gathering momentum. For instance, Schipper (1999:56) recalls that W.E.B. du Bois observed as early as 1903 that the problem of the twentieth century will be the "color line", which will be concerned with the "boundaries between insiders and outsiders [...] and the extent to which the color line served as a source of inspiration for writers as criterion for "real literature". Related to this premise is Schipper's concern with the role of intellectuals and artists as leaders that should realise their "special responsibility" which enables them to be spokespersons for "ordinary people" (Schipper (1999:56).

While Schipper's observations are premised on the experiences of The New Negro Movement, during The Harlem Renaissance, which was started by African Americans, Du Bois's views are as relevant today to Africans on the continent as they were then to those in the diaspora. Furthermore questions such as what inspires intellectuals and artists in their respective crafts, as well as what alerts them to recognise their special responsibility as spokespersons of the ordinary people, also remains critical in this era of Western dominated globalist perceptions of literary and political theory. In order to alert the African intellectual about the disguise of Western intellectual hegemony, which he terms the West's own indigenous myths in terms of a steam engine metaphor, Soyinka (1988:183) warns that:

You must picture a steam-engine which shunts itself between rather closely-spaced suburban stations. At the first station it picks up a ballast of allegory, puffs into the next emitting a smokescreen on the eternal landscape of nature truths. At the 
next it loads up with a different species of logs which we shall call naturalist timber, puffs into a half-way stop where it fills up with the synthetic fuel of surrealism, from which point yet another holistic world-view is glimpsed and asserted through psychedelic smoke. A new consignment of absurdist coke lures it into the next station from which it departs giving off no smoke at all, and no fire, until it derails briefly along constructivist tracks and is towed back to the starting-point by a neoclassic engine.

S.M. Guma as both an intellectual and a creative artist seems to be a well-placed author to interrogate in this respect in order to illustrate its manifestations in African literature. Guma appears by-and-large to express sentiments for the re-construction and affirmation of African identity by drawing knowledge from the past rich history of the Basotho. As Koka (1999:16) observes:

It is through the teaching of history that people come to realize and accept that, like their forefathers, they also have the ingenuity, power and ability to continue with the making of positive contributions to the welfare of the human society.

Basotho history was almost annihilated by, first, the French missionaries and secondly by British colonial occupation. These external forces almost left younger generations with nothing to learn from. However, Guma's novels seem to provide fertile ground for probing historical and cultural questions and to draw borders between people on the African landscape as well as to establish who are considered outsiders and insiders in the portrayal of the present complex global community.

Another crucial question also arises with regard to what makes issues of cultural and national identities such appealing subjects for the study of the literary history of nations at present. An immediate answer is that it lies in what makes history significant. As the embodiment of people, history is like a "clock that people can use to tell their time of the Day; and a compass that the people use to find themselves, and discover their identity on the Map of Human Geography" (Clarke, 1989:239).

In the following paragraphs the article will attempt to demonstrate the potential that Guma's novels have in contributing to the debate about Afrocentricity as a tool for re-establishing the history and cultural identity with reference to Sesotho literature in particular, and Basotho nationhood in general. 


\section{An overview of Sesotho literature (1960s-1990s)}

The period from the sixties to the nineties saw a proliferation of more than sixty creative works and a related upswing in a number of critical works in the study of Sesotho literature. Contributions such as Comparative literature and African literatures (1993), by A.S. Gerard et al. and the Southern African literature in African languages (1993), co-authored by D.B. Ntuli and C.F.Swanepoel, apart from a host of articles, theses and dissertations established a broad profile of Sesotho literature.

The people could, on the one hand, be considered adequate to give an aspiring reader/critic a glimpse of the historical development of the Sesotho novel. One would, however, also appreciate the fact that such literary and critical texts are time-, space- and ideologically bound. As a result such works also mostly responded to the demands of their times on the historical continuum. This means that such works were dictated by the very history - raw materials and ideologies - that characterised a particular era in the historical development of Sesotho literature. Missionaries and colonialists aimed at imposing these imperial perspectives on the African worldview, thus creating a monolithic literary tradition (cf. Selepe, 1999:90-130).

One such reality is the enduring tendency of studying African literature exclusively from a Western perspective. It is partly for this reason that African literature continues one of the most debated subjects that is not easy to define in comparison with literatures in other languages and/or from other countries. 1 To illustrate the importance of this line of argument, Barnett (1983:9) provides the following version of the development of African literature, sometimes called black literature:

Black creative writing in South Africa began in the middle of the nineteenth century with 'the missionaries', whose primary purpose was to publish reading matter for rather than by, the black man. It did not matter whether the translations of the Bible and religious works were written by whites or blacks, provided that the writers were proficient in the language in which they were writing and likely to reach the largest number of potential converts. When black writers did begin to produce works they were certainly encouraged to do so, and the mission press published many works. The Paris Evangelical

1 Such controversy revolves the question of language, nationality, ideology and influence. 
Mission press at Morija and the Church of Scotland mission station press at Lovedale became the centres of early black literature in the African languages. (Emphasis added - TJS.)

A further dimension that Barnett adds to the study of African literature, although mainly focusing on black South African literature in English, also has bearing on the Sesotho novel. She says in this regard: "Almost from the beginning of fiction writing [...] by black South Africans, it was a situation rather than individual characters and their interaction that interested authors" (Barnett, 1983:113).

Demonstrating the impact this format had on black South African literature, Barnett (1983:114) continues to argue that, as a result of oppression

... [African] fiction consequently took the form of protest against apartheid, a subject that lends it to short fiction rather than to sustain writing, unless the author follows the activities of a character from situation to situation. Since the situation was always the one experienced by the writer himself, the longer works were autobiographical rather than fictitious.

The views expressed above reinforce a notion that with the African novel it is material conditions that affected people, not just characteristic features of a literary work, which became an inspiration to authors. Lenake (in Gerard et al., 1993:130-133) makes another related observation with regard to events portrayed in the novels that were published during the period under consideration. He recognises that historical themes seem to have endured albeit without making reference to prevailing material conditions as an intrinsic inspirational factor.

In fact, Lenake seems to be content with merely slotting in the Sesotho novels published during this period into traditional slots of themes such as the Makgoweng motif (Jim goes to town), detective story, as well as conflict between traditional and modern life. He completely ignores their socio-political and historical situations and implications for cultural identity. As a result, the root causes and the range of the implications of such theories were never sufficiently explained nor deeply probed by traditional scholarship to give credible accounts of the effects of colonialism on African creative writing and critical perspectives.

As if to compensate for this omission, Ntuli and Swanepoel (1993) made a significant contribution, albeit in terms of ideological positioning, which can be regarded as a slight shift from the mode of 
thinking expressed in the foregoing paragraph. Ntuli and Swanepoel further regard novels published during the 1960 s to the 1990 s as characterised by historical themes and the clash between cultures. They never, at any point, go beyond these generalised views and reflect on the effects of industrialisation and urbanisation as well as related socio-political problems (Ntuli \& Swanepoel, 1993:9098). That is why this article will consider Guma's Sesotho novels in relation to the implications of the history-induced themes whose subject-matter resides in the sphere of actual historical events experienced by the Basotho rather than in the superficial perceptions of the Eurocentric version of the Basotho history.

\section{Some trends in the development of Sesotho historical novels}

Most Sesotho historical novels derive their inspiration from the institution of traditional leadership - kings and chiefs, linked to Lesotho, so to say. As historical data illustrate, by the 1960s British colonial rule in Lesotho was entrenched to a point where the role and powers of traditional leaders, in running the affairs of their subjects, was significantly curtailed. 2 At the same time in South Africa, where Afrikaner nationalism with its apartheid policies reached its heyday, similar institutions were also negatively affected (cf. Davenport, 1997:134-139). New roles were subsequently created for former chiefs in the concomitant establishment of illegitimate Bantustans ${ }^{3}$ by the former South African regimes. One would have expected therefore that the subject of traditional leadership could no longer serve as an inspiration and an appealing theme in the Basotho works of fiction from the sixties and beyond.

One possible explanation for this development could be the fact that imperial and apartheid publications gatekeepers seem not to have considered "historical fiction" as having socio-political and countercultural impact. For instance, considering that the erstwhile media policies denied the publication of what was branded "political material"; historical writing and analysis could have been regarded as an alternative by perceptive authors such as Guma, albeit as a

2 This observation does not ignore the independence Lesotho attained from Britain in 1966, where after the election of government, parliament, not monarchy ruled the country.

3 Some chiefs lost favour with their subjects as they were installed by an illegitimate South African regime. 
second choice. 4 Therefore, events portrayed seemed - at face value - to revolve around the Basotho traditional monarchy rather than the implications for imperial political systems imposed on the Basotho by external oppressive forces.

As a result of this error of judgment, no less than six novels were produced on this theme under the nose of the erstwhile gatekeepers, over and above other related works of poetry and drama. Another important point to mention here is that although such works are constructed around the traditional leadership in Lesotho - and other African nations to some extent - they still have relevance to the Basotho in the Republic of South Africa, who shares common ancestry with those in Lesotho. It is not a co-incidence therefore that Guma produced Morena Mohlomi, mor'a Monyane (1960), Tshehlana tseo tsa Basiea (1962) and Bitleng la Rasenate (1987). Majara produced Morena wa thaba (1963) and Morwetsan'a Moshate (1964) while the South African, Mopeli-Paulus' Moshoeshoe Moshoaila appeared in 1966.

To further demonstrate the appeal that the subject of traditional leadership or monarchy has among Basotho authors, one can mention Malefane's drama, Maru (1963), constructed around the Zulu king, Dingane, and Lesoro's poetry, Tau ya ha Zulu (1963), which deals with the life of another Zulu king, Shaka. Masiea's Mmualle (1984), which is based on intertribal marriages between royal families, saw the light in 1964. Another work is Booysen's drama, Sekhukhune (1989), in which the author claims to have been inspired by Mofolo's novel, Chaka (1927). This drama is constructed around the life of the Bapedi chief, Sekhukhune. Lastly, there is Mohapi's drama Leru le lefubedu (1994), which, if it is not a coincidence of intertextuality, seems to have been inspired by Guma's Bitleng la Rasenate (1987). The subject matter of both these works revolve around the renowned Ntwa ya dithunya (The gun war) (cf. Kunene, 1971 and Damane \& Sanders, 1974). Moiloa's masterpiece epic, Thesele, ngwana Mmamokgatjhane (1992) is another latest contribution that invokes the heroism and exploits of the founder of the Basotho nation and diplomat, king Moshoeshoe 1.

It comes as no surprise therefore that in Guma's imaginative novels we do not encounter a mixture of historical and ahistorical data. He 
seems to be entirely preoccupied with narrating authentic Basotho history.

\section{Some perspectives on Guma's novels}

Of all the authors who attempted to narrate the history of the Basotho, Guma (1923) stands head and shoulders above the rest for covering the widest spectrum of the legacy of the Basotho. This legacy demonstrates that the Basotho did not only contribute to the history of the Southern region but also how they successfully dealt with socio-political problems that arose from time to time (cf. Atkinson, 1993). A close examination of Guma's novels also exhibits a change of tone starting from his appreciation of the exploits of Basotho heroes and heroines to a bitter one in which he castigates the British colonial rule for sowing the seeds of division among the Basotho.

It is this perspective of the Basotho history and cultural identity that compels one to view it from an Afrocentric perspective. In pursuing this argument one needs first to concede that there is no "self" without reference to the "other" or "us" without reference to "them". The mystery of this symbiotic nature of identity is captured by Schipper (1999:31) who observes, that "[a]ll over the world, people have sought explanation for the mysteries of the environment around them. To the people of Africa, the rule of the white man was one of those mysteries." This situation obtains because as a result of the colonial legacy, the anomaly persists that Africans are generally compelled to firstly dispel Europeanised perceptions about them before they say who they are i.e. express their identity.

It is against this backdrop that Schipper (1999:30) observes further that "right from the first contacts, European and African literatures entered each other's cultural space". And the product of this interaction was not to become a multicultural space but a cleansing well from which the Basotho had been immersed and emerged from without a cultural identity. This assertion holds both for oral and written literature $-a$ view that is endorsed by several postcolonial and Afrocentric critics (cf. Ngugi, 1982 \& 1993). It is therefore within the interplay of this symbiosis that the national and cultural identity of the Basotho will principally be explored.

\subsection{Morena Mohlomi, mora Monyane}

The novel, Morena Mohlomi, Mora Monyane (Guma, 1960), deals with the life history of one of the early kings of the Basotho. 
According to Atkinson (1993:22), Mohlomi was born in 1710 and died in 1816. He is the son of Napo, a descendent of the Bakwena, who was also one of their former leaders. Among many of his attributes he is also known for his wisdom and diplomacy. He is the one who started to build the Basotho nation by peaceful means and not by war. It is also from Mohlomi that Moshoeshoe 1 learned about the expression kgotso ke kgaitsedi (peace is one's own sister) (Atkinson, 1993:26). In this novel, Guma portrays an unblemished history of the Basotho before colonialism.

Mohlomi's birth caused a few problems for the Bakwena. He was born a twin and this would have created problems as to who would succeed Napo after his death. 5 The one view was that one of the twins should be killed to avoid power struggle in the future. The other was that both should be allowed to live because the Bakwena have already had a similar case and no problem was experienced. The latter view prevailed and Mohlomi ultimately emerged as an heir to his father's throne above his twin brother. This matter also demonstrates, by and large demonstrates the genius of Afrocentrism in dealing with social problems peculiar to their situation.

Another instance that illustrates the ability of African society to develop and promote their culture as well as to manage their social and natural environment is that Mohlomi distinguished himself as a dependable leader in various ways. As a young man he was a good hunter and a good storyteller - some of the revered virtues among the Basotho. His peers, who enjoyed his interesting stories, always surrounded and listened to him with admiration in the evenings.

When the time came for him to take over the kingship from his father, he continued to amaze people around him. Unlike many kings who spent most of their time preoccupied with the affairs of their subjects, Mohlomi spent most of his time traveling and visiting other African nations in Southern Africa. In this instance Guma illustrates an old Sesotho adage, Matlo ho tjha mabapi (Neighbours (must) help one another). Mohlomi was also a traditional doctor, a craft that he learned from Rasebolai. Apart from healing many diseases, Mohlomi could also make rain. He also foretold the coming of the difaqane, also called leru la lerole le lefubedu (a cloud

5 Customarily a king holds his position and may not be replaced. 
of red dust), that would emerge from the east (cf. Atkinson, 1993:27).

Another important contribution that Mohlomi made in the advancement of Basotho culture is the advice he gave to Moshoeshoe 1 that made the latter one of the most venerated kings among the Basotho. Mohlomi gave him the following advice:

Mor'aka, u tla ba morena e moholo. Leha ho le jwalo, u tla lokela hore $u$ ithute ho busa sechaba sa hao ka bohlale. Ho molemo ho pola mabele ho feta ho leotsa lerumo. U lokela ho thusa sechaba sa hao ho phela ka khotso eseng ka lintoa. Haeba u ka phethisa sena, batho ba tla u rata, 'me ba be ba u mamele ho isa pheletsong ea bophelo ba hao (Atkinson, 1993:26).

My son, you'll be a great king. In spite of this you'll have to learn to rule your nation with wisdom. It is better to thrash corn that to sharpen spears. You have to teach your nation to live in peace and not war. If you do this, people will love and listen to you until your death.

The account, which Guma portrays around Mohlomi's life, demonstrates that the early history of the early indigenous African people is not necessarily that of savagery and backwardness. It is a history of peace and progress where various nations did not only meet when they waged war but also met when they were building friendship. While this historical account seems fictionalised in the novel, it nonetheless remains a hallmark of the culture and the identity the Basotho had cultivated among themselves. It is a proud history, which demonstrates that peace and progress from which future generations could learn about virtues. The story of this novel is constructed around known historical figures, events and places, and it stands as a unique account of one of the unacknowledged ambassadors of peace and progress in the subcontinent. Such peace was at times achieved, especially in precolonial Africa, by marrying among nations other than one's own.

Another important dimension that Guma brings out in this story is the origin of madimo (cannibals). According to him, Mohlomi first learned about cannibals among the vhaVenda people in the former Northern Transvaal or the present Limpopo Province. That was long before the difaqane wars, which were allegedly caused by the Zulu king, Shaka, and had led to famine and the displacement of many indigenous communities. As a result of the famine some starving people started eating other human beings and were labeled madi- 
mo. Guma does concede, however, that the difaqane (Shaka's wars) was not the only cause of cannibalism as it will be demonstrated in the next novel.

In the current novel few hallmarks of the Basotho's cultural identity are being addressed. Firstly, the Basotho attached great importance to peace and national stability. It has been pointed out how the problem of the twins that nearly posed a threat to the succession of monarchy was resolved. It was also pointed out that Mohlomi traveled a lot to make friends with other indigenous nations, which today could be termed establishment of diplomatic ties. From this it could be deduced that there was some form of devolution of power because in the absence of the monarch there would always be someone to look after the affairs of the nation at district and regional levels. Hence the Sesotho dictum: Morena ha a ete (The king is never absent) (cf. Sekese, 1993; Guma, 1971).

Secondly, it has been realised that the functions of a traditional monarch were not confined to ruling only. He also took responsibility for other issues that affected his subjects. For instance, Mohlomi also looked after the health aspect of his subjects because he was also a traditional healer. He also dealt with natural calamities, e.g. by causing rainfall in the event of drought or averting other forces of nature that tend to threaten their well-being. 6 This underlines the Basotho's strong belief in nature and its cosmology, which they regard as part and parcel of their sacred life. It is inter alia around such beliefs that Africans generally value virtues of ubuntu/botho (humanness) upon which modes of social interaction were built, including respect for nature and the cosmos. The evidence of this is found in their myths, rituals and religious practices, which form the corner stones of the Basotho cultural identity (cf. Matsela, 1997). The next novel, Tshehlana tseo tsa Basia takes this subject of cultural identity to the next level, indicating that gender discrimination is alien to Africa.

\subsection{Tshehlana tseo tsa Basia}

The third novel is Tshehlana tseo tsa Basia (Gumede, 1962) where Guma again portrays a history of the Basotho as yet untouched by colonialism. Unlike in the case of Mohlomi, Guma in this novel portrays the history that was characterised by strife, deceit and power 
mongering. In this novel Guma portrays the significant role played by the Basia damsels (cf. Ashton: 1967), Ntlokgolo and Manthatisi who were married to the Batlokwa chiefs Montwedi and Mokotjo, respectively. There were two distinct clans among the Batlokwa: ${ }^{7}$ the Batlokwa who lived around the present Harrismith and the Basia who lived around the present Zastron. Guma also uses many names of historical figures such as Moshoeshoe, Shaka, Rakotsoane, et cetera, place names such as Harrismith, Phiritona (Heilbron), Matlakeng (Zastron), et cetera (cf.Ellenberger: 1988). This is also evidence of the geographic space that the Basotho occupied before the advent of colonial resettlement that later deprived them of vast tracts of land, and ultimately confined them to the present tiny Kingdom of Lesotho.

Motonosi is a Batlokwa chief who is succeeded by his elder son, Montwedi. Montwedi marries a daughter of the Basia, Ntlokgolo. Montwedi and Ntlokgolo, the senior wife, could not have children, until very late. They are later blessed with a baby boy, Mokotjo, but Montwedi dies shortly after the birth of this son. After Montwedi's death, Montwetsana, the former's younger brother attempts to marry Ntlokogolo as it was a cultural practice to do so. However, Montwetsana's intention was to usurp the chieftaincy by remarrying his late brother's wife. Ntlokgolo rejects his advances. This refusal leads to a bitter feud between the two. Ntlokgolo is forced to flee away to save hers and her son's lives. She is helped by Mantwa (Fighters) - a group loyal to Montwedi - to return to her people, the Basia, who are still living around Matlakeng (Zastron) (cf. Ellenberger: 1988).

Mokotjo grows up among the Basia and after his initiation he is again helped by the Mantwa group to succeed his father as chief of the Batlokwa. While at Matlakeng, Mokotjo meets his cousin, Monyaduwe whom he later marries. The latter is renamed Manthatisi by the Batlokwa. Mokotjo also dies at a very young age but the events which characterised his father's death are not repeated. Manthatisi takes over as regent of the Batlokwa. According to Atkinson (1993:37) Manthatisi was born in 1785 and died in 1840. Under her leadership the Batlokwa fight many battles and grow to become one of the big tribes. A desire to find a fortress leads the Batlokwa to the present Lesotho where they find a stronghold at

7 The Batlokwa also include the Bataung, Batloung, Baphuthing, Basia, Bakoena and Bathepu clans (cf. Ashton; 1967:17). 
Butha-Buthe. At the time of their arrival, Moshoeshoe 1 had just left Butha-Buthe and had moved to Thaba-Bosiu - a fortress whose history is well-documented. 8

The intertribal wars which were fought at the time as well as Tjhaka's reign of terror and the difaqane, lead to famine and subsequently the emergence of madimo (cannibals). Another effect of the difaqane is the breaking up of tribal unity as well as the merging of other tribes. For instance, it is a well-known fact that Moshoeshoe 1 built the Basotho nation out of splinter tribes. Guma also mentions that the Batlokwa too had at some stage also brought other tribes into their fold through conquest or by granting them refuge.

This novel also contains a few lessons about the Basotho identity and nationhood. The one lesson is that while patriarchy was a dominant feature of social systems in most communities, the Basotho were and are not dogmatic about this feature. That is why there were and still are women who serve as regents in their respective tribal communities while the rightful heirs are still growing up. The other important lesson is that the Basotho are not a homogeneous nation but a constellation of several tribes. Maphike (in Gérard et al., 1993:118) makes the following observation in this regard:

This novel seems to be a product of the interplay of several factors including the writer's experience. It seems to reflect subtly on the solidarity of the heterogeneous Fort Hare populace prior to the advent of Bantu education by analogy with the solidarity of the Bakwena tribe prior to the birth of the twins. ${ }^{9}$

That is why it is important, to study not only literary works, but also the history and culture of the Basotho at both the macro and micro level in order to locate and establish their identity reasonably well. A balanced view of what is perceived from outside and what is located inside is therefore imperative. As Amuta (1989:129) observes:

In order, therefore, to establish the formal identity of the set of related fictional products that we have come to know as the

8 Cf. Kunene (1971) and Damane and Sanders (1974).

9 The subsequent apartheid regimes preferred separation of tribes and races, which resulted in the formation of homelands. 
African novel, we need to return to the dialectical relationships [...]. To the extent that a certain historical concept defines the African novel, the narrative mediations of that context into definite works [...] are bound to bear the stamp of their specific determination.

Lastly, the events that are narrated in this novel, the epistemology of which embedded in realism, have a bearing on what was to happen later in the history of the Basotho i.e. forcibly introducing them to the industrial world with its concomitant capitalist mode of production (cf. Selepe, 1993 \& 1999). With their land significantly reduced, the Basotho became a reservoir for cheap labour in commercial farms as well as the mining industry that were emerging in the then white South Africa. The laws that governed their migration had a negative impact on the family as well as on the social and moral fabric of the Basotho.

Consequently, their identity as a self-sustaining nation was changed to that of a dependent one. Their social status in South Africa was also reduced to that of the lowest class, together with other indigenous people. While historical events that have been portrayed so far are confined to the interiority of a national domain, events to come are to be of an international nature. In the next novel, Bitleng la Rasenate (1987), Guma explores the latter dimension of the Basotho history.

\subsection{Bitleng la Rasenate}

Bitleng la Rasenate is the latest novel written by Guma (1987), and it depicts the latest history of the Basotho and portrays one of the historical events that have led to the present state of affairs in Lesotho. In 1868 Woodhouse annexed Lesotho while under the reign of Moshoeshoe 110 - the event which signaled the beginning of the end of Basotho nationhood (Fowler \& Smit, 1973:18). However, Guma creates his story around the events that lead to the total fragmentation of the national unity of the Basotho as a result of the historic Ntwa ya dithunya (The gun war) that was fought from 1880 to 1883 (Ashton, 1967:5).

It is this war that finally broke the backbone of the Basotho culture by instigating factionalism. The chiefs Lerotholi and Jonathane, who were cousins, divided the Basotho. The former fought the British 
over the expropriation of the guns the Basotho had acquired legally while the latter did not. The story demonstrates how the interference of British has succeeded in subjugating the Basotho by causing division within their ranks through the exploitation of the federal nature of their political system, which tested their loyalty and patriotism to the British to the limit (cf. Atkinson, 1993:62-68).

The division wrought by this invasion became manifest in the leadership structures of the Basotho nation. The British exploit this factionalism to their own advantage by communicating only with the faction who was willing to hand over the guns. The faction of Mashwelatoka (the martyrs) that opposes the handing over of the guns was led by Lerothodi11 while the other faction, Maloyale (the loyalists), was led by Jonathane who is recognised by the British as the only legitimate voice of the Basotho. Their support to Jonathane was lukewarm, because he delayed taking a position on the question of the surrendering of the guns. It was only when the battle had become a full-scale war and after Captain Spriggs was sent to intervene that Jonathane explicitly pledged his support to the decision of the British. By that time the strain of the war had taken its toll on Lerothodi's regiments and they were on the brink of defeat after the British received reinforcements.

The effects of the war are evident and a cease-fire seems to be the only alternative but it came at an unexpected price. Instead of reciprocating Jonathane's goodwill, the British punish the whole Basotho nation because of the actions of Lerotholi's rebels. The Basotho are made to pay the costs of the war with cattle and when the required number of cattle could not be raised the areas of Matatiele and Herschel are annexed by the colonial government.

Captain Spriggs successfully brokers the cease-fire and Jonathane ends the war but this process does not benefit the Basotho in any way. Reflecting on the document announcing the cease-fire and the accompanying penalty, Guma (1987:73) wrote:

Ngolo lena la kahlolo la fihla ka morao ho nako e telele. La ya ballwa hona mane Maseru, marena a le teng kaofela, e le kgetlo la pele a teana ha esale ntwa e ne e qalehe. Dintlha tsa lona tsa bohlokwa di ne di le tharo. Ya pele e ne e re marabele

11 Actually Letsie 1, Moshoeshoe 1's son, with the support of Lerothodi, was instrumental in waging this and other boarder wars (cf. Microsoft Encarta Encyclopedia Standard, 2004). 
a ipitsang Mashwela toka a kwenehetse mmuso a ba a o Iwantsha. Ka baka leo mmuso wa tlameha ho bula banka ya ho jara ditshenyehelo tsa ntwa eo. Ya bobedi, e re Maloyale a bitswang Mateketwa, a He a amohuwa di-tsa-bona, a ba a baballwa ke mmuso ka ntho tsohle. Ya boraro ke ditshenyehelo tse ding kaofela tsa ntwa kaofela ha di se di kopane tsa akaretswa ka dikete tse hlano tsa dikgomo. Ha thwe ena ke yona kotlo ya pele ya bona, tse ding di tla tloha di bolelwa. Tefo ya dikgomo tse badilweng e honyelle kaofela ka nako e le nngwe. Ha ho ka ba jwalo, naha e tla dula e ntse e le jwalo matsohong a bona. Empa ha di sa honyelle kaofela, naha e tla kgepholwa, ho nkuwe koto se seng sa yona ho lefa me/a to e setseng.

This judgment letter came after a long time. It was read at Maseru where all the chiefs were present, the first time since the beginning of the war. It contained three important points. The first one stated that the rebels who called themselves Mashwelatoka have rebelled against the government and even fought against it. For that reason the government was forced to open a bank account that would enable it to meet the expenses incurred in that war. The second point stated, that Maloyale, who were called Mateketwa, were dispossessed of their belongings and had to take care of them. The third related to all other expenses of the war that amounted to five thousand heads of cattle. It was stated that this was the first penalty and that the other would follow. The number of cattle required had to be paid at once in full. If that happened, the land will remain theirs. But if they failed, part of the land equivalent to the deficit would be taken.

The content of the penalty as portrayed by Guma demonstrates undisguised deceit and cruelty of the British colonial rule. It refers to expenses, which the British have incurred by protecting the loyal faction whose property has also been confiscated by Mashwelatoka. It makes no mention of a similar act that the British have perpetrated against the Basotho in general by compelling them to surrender their legally acquired guns. The other unspecified costs also demonstrate how the British are bent on milking the Basotho dry so that they should forever depend permanently on the former's generosity. This implies that if the British had disclosed all the costs, the hidden costs would have been used to achieve the same objective, i.e. to take away everything the Basotho have thus making sure that they should never again rise against the British.

The irony of the whole scenario is that both the British and the Basotho in either defending what they have or regaining what they 
have lost committed the same wrongful acts - to fight. However, in the end the British emerged as both the complainants and the judges while the Basotho are reduced to outright villains whose actions cannot be rationalised. Using George Tladi's observation in one of the court hearings before the war, Guma (1987:50) gives a convincing answer to this question when he says:

Ho hlakile hore molato ke mmala ona wa rona oo re o filweng ke Modimo. Ha le re thetsa kwana dikolong le ye le re batho ba a lekana. Empa eka bophelong ba ka ntle, ba bang ba lekana ho feta ba bang. Ho na le molao wa ba matla, le o mong nape wa ba fokolang. Re amohuwa dibetsa fee/a hobane re le matla re bile re fokola, mme ntho eo e bohloko.

It is quite clear that the problem is our colour, which God has given to us. When you lie to us at school you often say that people are equal. But in real life some are more equal than others. There are laws for the strong and other laws for the weak. Guns are being taken from us because we are not strong but are weak, and this is painful.

This is a humbling observation that characterises the pattern of life throughout the so-called civilised world: "Obey the strong and oppress the weak." However, experience has shown that generally the strong are the weak that conform and the weak are the strong that refuse to conform. The price paid by the latter is to be jostled out of all forms of advancement to prove their "weakness". Guma portrays this situation by contrasting the position of the martyrs (Mashwelatoka) and the loyalists (Maloyale) as follows:

Boemo bona ba marabele ha bo bapiswa le ba dikampong, bo ne bo itshwanela hantle fee/a le ba phokojwe e bolelwang ditshomong tsa Basotho. Ho thwe ya teana le ntja e nonneng haholo, boya ba yona bo bile bo phatsima. Phokojwe ya e botsa hore na dijo e di fumana kae hara lee? Ya re e di fuwa ke monga yona. Phokojwe ya e botsa hore a na le yona a ka e fa na? "E, a ka o fa". Tsa tloha ho ya teng. Em pa tseleng phokojwe ya elellwa hore ntja ha e na boya molaleng hoba e ne e tsamaya e ntse e qamaka, e tsota monono wa yona. Ya e botsa hore na bo entse jwang? Ntja ya sheba fatshe ya re bo phumotswe ke lerapo hoba monga yona o a e holeha bosiu. Phokojwe ya hlahafala, ya re, "O reng? O re o hie a o holehe ka thapo, a o sitise ho ikela moo o ratang? Tjhe, mokane, boela ho monga hao le dijo tsa hae tsa thapo ya mehla. Nna nka mpa ka bolawa ke tlala ho ena le hore ke tele bolokolohi ba ka". Phokojwe ya rialo e peralatsa mosela e boela morung, serameng le tlaleng ya bolokolohi, ha ntja e tsoka wa yona e boela ho monga yona. (Guma, 1987:71.) 
The situation of the rebels in comparison with those in the camps was similar to that of the fox in Sesotho folk tales. They say that the fox met with a very fat dog, whose hair was shining. The fox asked him where he got food from during that period of starvation. The dog replied that he got food from his master. Then the fox asked whether he could also be given food. 'Yes, he can also give you food.' Then they walked together to the dog's master. But along the way the fox realised that the dog had no hairs around the neck, because he was so fascinated by the dog's fatness. He asked the dog what had happened to it. The dog looked down and explained that it had been removed by the thong strap because his master chains him at night. The fox was bewildered and asked, 'What do you say? Do you really mean that he chains you with a thong and prevents you from going where you want to? No, my friend, go back to your master; to his food and the daily chain. l'd rather starve than sacrifice my freedom.' The fox uttered these words lifting his tail and going back into the forest, to the cold and starvation of freedom, while the dog wagged his tail on his way back to his master.

The British created a situation that would force choices that would rip the Basotho nation asunder. The British designed a situation that would enable them to reward those who obey them and punish, in most severe ways, those who are perceived to be disobedient. Such a choice, as inferred earlier, has no moral basis but was based on deceit and exacted a huge price for survival. In its most obnoxious form this trend is that the imperial forces create a desperate situation for those who question their tactics and then turn around to appear as philanthropists giving humanitarian aid to the suffering. They would never feed a dog that bites their hand, while on the other side they sustain the poverty of the obedient through "humanitarian aid" rather than development.

In addition even that section of the Basotho that gave in to the demands of the British voluntarily was never considered to be part of the Britons. They were not even considered to be "honorary British" as a reward for their loyalty. While political ambitions could appear as a primary motive, the underlying racial factor cannot be overlooked. It was therefore not only on the basis of their military strength that the British considered themselves superior to the $\mathrm{Ba}$ sotho. It was also because of their colour - a natural feature into an ideology of supremacy and subordination.

This is a kind of situation that many Africans, the wretched of the earth as Frantz Fanon purports, are still faced with today in some 
situations. If they want to become part of the mainstream of world developments, they have to be prepared to be subordinate and chained forever. If they choose freedom, they have to be prepared to starve forever. These are some of the consequences of the 1884-1885 Berlin Conference whose resolutions have inter alia reduced Africa to the perpetual status of subservience in all spheres of life (cf. Fowler \& Smit, 1973:91-92).

Bitleng la Rasenate, as opposed to Guma's two earlier novels, has an unmistakable tone of bitterness. One could assume that this bitterness is a result of experience that has proved that there is not much that Africa and Africans could do about their situation as long as the interests of the Western powers direct affairs. Perhaps this experience is that the former colonial powers in particular, and the Western world in general, were prepared to give handouts to sustain poverty, but they were not prepared to eliminate it through appropriate and sustainable developmental programmes that would eliminate the effects of colonialism. The Western world today, in a replay of apartheid in South Africa, is also prepared to develop individuals or groupings, but not the entire black nation, even if such selective deployment could lead to national suicide. Meredith (2005:42) interprets this tendency as follows with regard to South Africa:

Whatever signs of black discontent there were, the government pressed on with its policies of grand apartheid as determinedly as before. The final solution for the African population, as apartheid's architects saw it, was no longer simply self-government for the homelands but 'independence'. By bestowing independence on the homelands, the government would be able to remove all claim that the African population had to South African citizenship.

Some African nationals in other countries could not also enjoy the benefits of citizenship in countries of their birth. Guma's fictionalisation of the Basotho history makes an unique contribution to the Sesotho novel. In the first two novels, Morena Mohlomi, mora Monyane and Tshehlana tseo tsa Basia, Guma locates the history of the Basotho in a subdued tone in their ancestral land in parts of the present Free State province. In Tshehlana tseo tsa Basia, in particular, Guma demonstrates that areas such as Phiritona (Heilbron), Harrismith and Zastron were part of the Basotho land.

This claim is supported by the fact that most of the important names in the Batlokwa history, remain part of the present history of 
the Batlokwa who are found in the southern parts of the former Qwaqwa bantustan, in the Eastern Free State. Members of the Sekonyela lineage are district chiefs in the Thibella district of Tsheseng. One of the first high schools at Tsheseng has been named after the Batlokwa chieftainess, Manthatisi. In the village of Phomolong east of Manthatisi High School there was in the early eighties also a traditional councilor called Selepe. All these names are consistent with the historical names of the Batlokwa used by Guma in his novel, affirming the existence of a stable identity that is derived from a stable but evolving culture as opposed to just a hybrid culture.

\section{Conclusion}

This article argued that historical events between the 1960s and 1990s have contributed to certain ideological and perceptual shifts in the Sesotho novel. Such ideological and perceptual shifts have affected both creative writing and literary study in various ways. Some of the effects have been explicit while others have been implicit, and it is this trend which underlines the main argument of this article: a tendency to give Africans a distorted history, culture and identity and disguised the purposes of the nobility of this world. That is why even today, "until lions have their own historians, the stories of hunting will always glorify the hunter" (old African adage).

An important dimension of the argument in this article is, however, that there is not necessarily a one-to-one correspondence between literature and society. There is, instead, a dialectical relationship between history - as perceived Africans - and society that is mediated by literature (cf. Amuta, 1989:82). It is for similar reasons that Keto (1989:1) argues that: "The Africa-centered perspective of history rests on the premise that it is valid to posit Africa as a geographical and cultural starting base in the study of peoples of African descent."

What determines African identity is their motherland, Africa - the over-arching effect of colonialism as well as their response to that condition. This has been discerned from the manner in which both authors and critics have responded to prevailing social conditions during the era of oppression (colonial and neo-colonial) and resistance, 12 the attainment of freedom and the long-awaited era of

12 Cf. the Basotho heroic poetry and praise poems by Kunene (1971), and Damane and Sanders (1974), respectively. 
reconstruction and development. In other words their common historical experience on the African continent and the Diaspora forms the basis of their collective identity.

The article has also found that there is no dichotomy between Africa's past and present history and a continuity (cf. Oyebade, 1990:235). Most importantly the article has found that by focusing on literature alone, ignoring the historical contexts that produced it, cannot provide effective mechanisms for addressing the problems surrounding literary study with a view of understanding and affirming the cultural identity of African people.

Finally, the truth about Africans in general, and the Basotho in particular, can best be established by acknowledging that the "need to create an African - centered perspective that takes Africa as a point of departure for African studies stems from the nature of the Eurocentric paradigm, which has been used in many previous African studies" (Oyebade, 1990:234). From this perspective it can also be established that African culture is not static or simply hybrid as globalist perceptions in literary and political theory would have it (Asante-Darko). As Spillers (1998:4) observes: "But you take the 'local' with you, whatever your 'local' is, into these various cultural and theoretical zones."

\section{List of references}

AMUTA, C. 1989. The theory of African literature. London: Zed Books.

ASHTON, H. 1967. The Basuto: a social study of traditional and modern Lesotho. London: Oxford University Press.

ATKINSON, N.D. 1993. Tsa Likoankoetla le bahale naheng ya Lesotho. Maseru: Macmillan Lesotho.

BARNETT, U.A. 1983. A vision of order: a study of SA literature in English (1914-1980). Cape Town: Maskew Miller Longman.

CLARKE, J.H. 1989. African people in world history. Cornell: Cornell University Press.

DAMANE, M. \& SANDERS, P.B. 1974. Lithoko: Sotho praise poems. Oxford: Clarendon.

DAVENPORT, T.R.H. 1997. South Africa: a modern history. London: Macmillan Academic \& Professional.

ELLENBERGER, D.F. 1988. Histori ea Basotho: Mehla ea boholo-holo. Morija: Morija Sesuto Book Depot.

FOWLER, C. de K. \& SMIT, G.J.J. 1973. Senior history. Cape Town: Maskew Miller.

GUMA, S.M. 1960. Morena Mohlomi Mor'a Monyane. Pietermaritzburg: Shuter \& Shooter.

GUMA, S.M. 1962. Tshehlana tseo tsa Basiea. Pietermaritzburg: Shuter \& Shooter. 
GUMA, S.M. 1976. The form, content and technique of traditional literature in Southern Sotho. Pietermaritzburg: Shuter \& Shooter.

GUMA, S.M. 1987. Bitleng la Rasenate. Pietermaritzburg: Shuter \& Shooter.

KETO, T. 1989. The Afro-centered perspective of history. New Jersey: K.A. Publications.

KOKA, K. 1999 The Afrikan Renaissance: Afro centric perspective. Midrand: Afrikan Study Programme.

KUNENE, D.P. 1971. Heroic poetry of the Basotho. Oxford: Clarendon.

LENAKE, J.M. 1993. The development between 1960 and 1990. (In Gerard, A.S. Comparative literature and African literatures. Pretoria: Via Afrika. p. 129-138).

MAPHIKE, P.R.S.1993. The development between 1900 and 1960. (In Gerard, A.S. Comparative literature and African literatures. Pretoria: Via Afrika. p. 91-128).

MATSELA, F.Z.A. 1997. Mahakwe a tsela. Maseru: Macmillan Boleswa.

MEREDITH, M. 2005. The fate of Africa: from the hope of freedom to the heart of despair: a history of fifty years of independence. New York: Public Affairs.

MICROSOFT ENCARTA ENCYCLOPEDIA STANDARD. 2004. Lesotho.

NGUGI, WA THIONG'O. 1982. Writers in politics. London: Heinemann.

NGUGI WA THIONG'O. 1993. Moving the centre. London: Currey.

NTULI, D.B.Z. \& SWANEPOEL, C.F. 1993. Southern African literatures in African languages. Pretoria: Via Afrika.

OYEBADE, B. 1990. African studies and the Afrocentric paradigm. Journal of black studies, 21(2):233-238.

SCHIPPER, M. 1999. Imagining insiders: Africa and the question of belonging. London: Cassell.

SEKESE, 1983. Mekgwa le maele a Basotho. Morija: Morija Book Sesuto Depot.

SELEPE, T.J. 1993. Contemporary black protest literature in South Africa: a materialist analysis. Pretoria: Unisa. (Unpublished M.A. dissertation.)

SELEPE, T.J. 1997. Liberating the teaching of literature in a democratic South Africa: a pedagogy of reconciliation. South African journal of African language, 17(2):80-84.

SOYINKA, W. 1988. Art, dialogue \& outrage: topical excerpts from texts by whole Soyinka. http://prelectur.stanford.edu/lecturers/soyinka/ excerpets.html Date of access: 29 Oct. 2001.

\section{Key concepts:}
Afrocentricity
cultural identity
deculturation
imperialism
literary theory
Sesotho culture
Sesotho novel 
Kernbegrippe:

Afrosentrisme

dekulturasie

imperialisme

kulturele identiteit

literatuurteorie

Sesothokultuur

Sesothoroman 
